\title{
Assessment of Heavy Metal Pollution in the Water, Sediment and Fish during a Complete Breeding Cycle in the Pond of the Pearl River Delta, China
}

\author{
Benjian Mao1, Zhiwei Huang2, Fantang Zeng'2, Hongwei Du², Huaiyang Fang², Shu Lin², \\ Yuyu Zhang ${ }^{1}$, Lei Shi ${ }^{*}$
}

${ }^{1}$ Guangdong Key Laboratory of Environmental Pollution and Health, School of Environment, Jinan University, Guangzhou, China

${ }^{2}$ National Key Laboratory of Water Environmental Simulation and Pollution Control, Guangdong Key Laboratory of Water and Air Pollution Control, South China Institute of Environmental Sciences, Ministry of Environmental Protection of the People's Republic of China, Guangzhou, China

Email: *tshilei@jnu.edu.cn

How to cite this paper: Mao, B.J., Huang, Z.W., Zeng, F.T., Du, H.W., Fang, H.Y., Lin, S., Zhang, Y.Y. and Shi, L. (2020) Assessment of Heavy Metal Pollution in the Water, Sediment and Fish during a Complete Breeding Cycle in the Pond of the Pearl River Delta, China. Journal of Environmental Protection, 11, 509-530. https://doi.org/10.4236/jep.2020.116030

Received: May 2, 2020

Accepted: June 25, 2020

Published: June 28, 2020

Copyright $\odot 2020$ by author(s) and Scientific Research Publishing Inc. This work is licensed under the Creative Commons Attribution International License (CC BY 4.0).

http://creativecommons.org/licenses/by/4.0/

\section{(c) (i) Open Access}

\begin{abstract}
The paper aimed to investigate the concentration variations and evaluate the bioaccumulation as well as the health risk of $\mathrm{Cr}, \mathrm{Ni}, \mathrm{Cu}, \mathrm{Zn}, \mathrm{As}, \mathrm{Cd}$ and $\mathrm{Pb}$ in the aquaculture pond ecosystem during a complete breeding cycle. The samples of water, sediment and aquatic organisms were collected from the pond of gull island in the Pearl River Delta, China. In the breeding cycle, the results revealed the metal concentration in the water increased, while the sediment metal concentration showed no significant difference. The heavy metal concentrations in the water were higher than the background values (December 2017) which related to the input of feeds. Sediment metal concentrations $(\mathrm{Cr}$, $\mathrm{Ni}, \mathrm{Cu}, \mathrm{Zn}, \mathrm{As}$ and $\mathrm{Cd}$ ) in the sediment were higher than the background values of Guangdong Province, China, indicating these metal pollutions came from anthropogenic activities. While the concentration of $\mathrm{Pb}$ was comparable to the background value, implying that the $\mathrm{Pb}$ was mainly from the earth crust. In addition, various metals showed different affinity to fish organs (muscle, skin, bladder, gill, heart, kidney and liver). Zinc was abundant in skin, while As and $\mathrm{Cd}$ concentrations were highest in kidneys; $\mathrm{Cu}$ was accumulated highest in liver; $\mathrm{Cr}$ concentrations was highest in hearts; and $\mathrm{Ni}$ was mainly found in bladders, and the $\mathrm{Pb}$ was most commonly found in gills. The distribution of heavy metals in the tissues organs was in the sequence of: $\mathrm{Zn}>$ $\mathrm{Cu}>\mathrm{Cr}>\mathrm{Ni}>\mathrm{Pb}>\mathrm{As}>\mathrm{Cd}$. As the fish ages, the $\mathrm{Cu}$ and $\mathrm{Zn}$ concentration
\end{abstract}


in tissue organs declined, while the $\mathrm{Cr}, \mathrm{Ni}, \mathrm{As}, \mathrm{Cd}$ and $\mathrm{Pb}$ increased slightly. Estimations of health risks showed no evidence of potential threats to consumers.

\section{Keywords}

Heavy Metals, Risk Assessment, Breeding Cycle, Grass Carp, Fish Organs

\section{Introduction}

In recent decades, with the increase of significant population and rapid industrialization, the Pearl River Delta (PRD) has undergone rapid economic development. Heavy metals pollution caused by anthropogenic activities has been reported in various studies [1] [2] [3]. In PRD region, river water is still used to fill up the fish ponds by most of the fish farmers [4]. Heavy metals may enter fish ponds through the sewage outfalls, industrial runoff and atmospheric deposition. Moreover, the fish feeds have been regarded as the main sources of some metals to aquaculture environment [5]. Metal contamination in water, sediment and aquatic organisms has attracted widely attention due to their toxicity, persistence, bioaccumulation and biomagnification [6]. If the concentration of the metal accumulating in fish tissues was higher than the permissible maximum value, an adverse health risk will generate.

Metals contamination in the PRD is focused on offshore aquaculture [7] [8], but little information about fresh water fishs pond environments [1]. In addition, muscle was the major organs analyzed in most studies [9] [10] comparatively; there is less research on other fish organs. This is the first study to analyze the variations of metals concentration in the water, sediments and tissue organs (muscle, skin, bladder, gill, heart, kidney and liver) during a complete breeding cycle. To investigate the transformation and bioaccumulation of metals in those tissue organs in the breeding time, this information will be helpful for fisheries management in freshwater fish pond environment.

Therefore, this study was presented to address the above-mentioned issue, and the objective was to: 1) investigate the 7 metal levels in water, sediments and various fish tissue organs during a complete breeding cycle; 2) assess the pollution levels and potential ecological risk of heavy meals in sediments; 3) estimate the transfer, bioaccumulation and human health risk.

\section{Materials and Methods}

\subsection{Study Area}

Gull island is located in the eastern suburbs of Guangzhou, China. It is surrounded by the main channel of the Pearl River and the Lotus Mountain Waterway. As one of the main breeding areas in Guangzhou, gull island is mainly used for the cultivation of four famous domestic fishes (Grass carp, Mylopha- 
ryngodon piceus, Hypophthalmichthys molitrix and Aristichthys nobilis). About 30,000 tons of fish products are provided for Guangzhou and other regions from the gull island every year. A fish pond selected in the gull island is representative to explore the variations of heavy metals in the fish pond ecosystem during a complete breeding cycle. A total of $670 \mathrm{~kg}$ of grass carp fry (weight 150 - $250 \mathrm{~g}$ ) was put into the pond covering an area of $2160 \mathrm{~m}^{2}$ in December 2017 and six months were set as a complete breeding time according to the local breeding experience.

\subsection{Field Sampling}

A total of 108 surface water, feeds and sediment samples were collected in triplicate, as well as 46 fish samples were obtained from the pond in gull island, China (Figure 1) during December 2017 and January, March, April, May and June of 2018. Surface water samples ( $50 \mathrm{~cm}$ below the air-water interface) were collected in polyethylene bottles. Feed samples were obtained from the fish farm and stored in polyethylene bags. Surface sediment samples (to a depth of $10 \mathrm{~cm}$ ) were collected using a Petersen's grab and sealed in polyethylene bags. At the same time, fish samples were captured using fishing nets and sealed in polyethylene bags in an ice cube box. All samples were transported to the laboratory immediately after collection. The water, feed and fish samples were kept at $4^{\circ} \mathrm{C}$ until processing, whereas the sediment samples were frozen at $-20^{\circ} \mathrm{C}$ before further analysis.

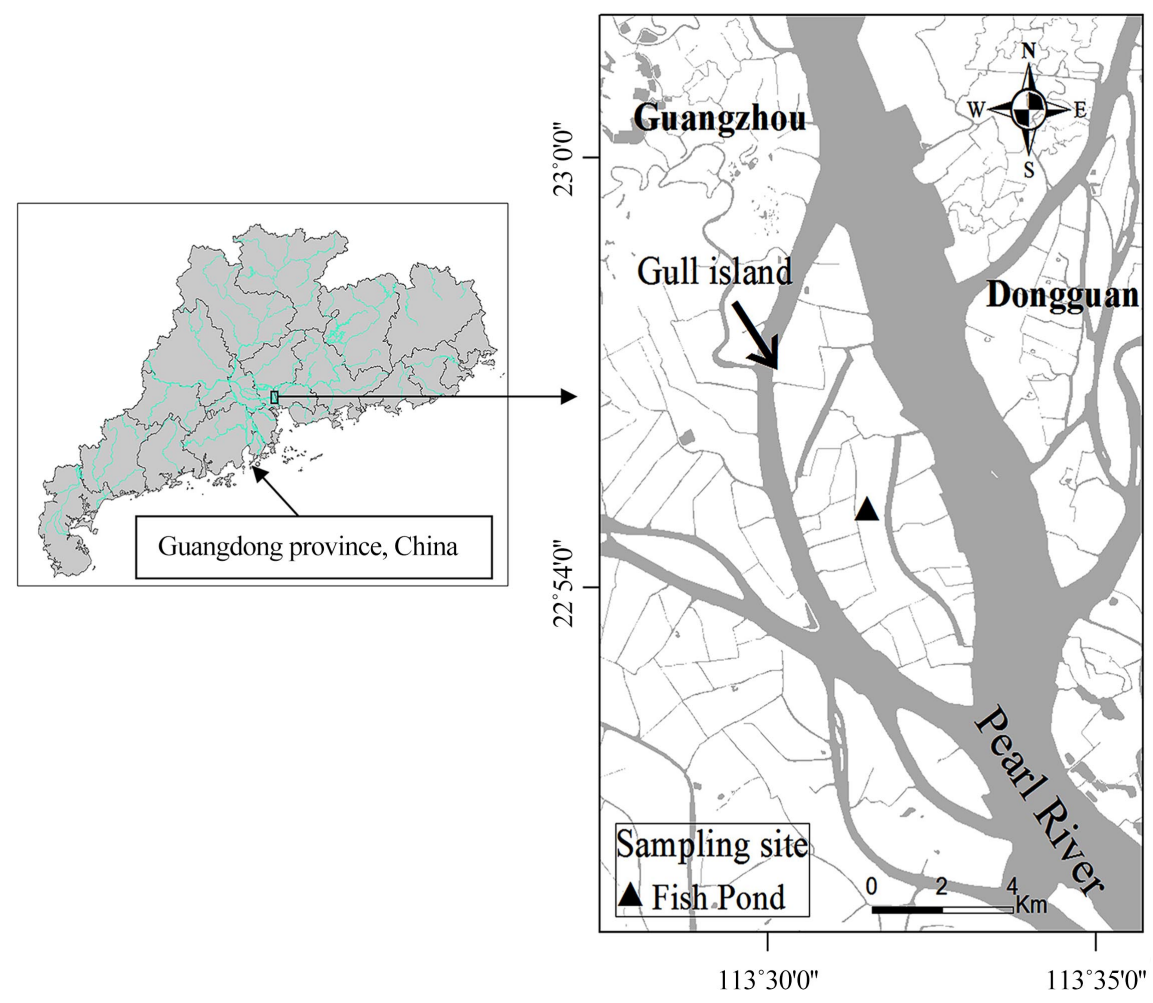

Figure 1. Map showing the sampling site in the pond in the gull island located in the Pearl River Delta, China. 


\subsection{Sample Pretreatment and Metal Analysis}

Water was acidified with $\mathrm{HNO}_{3}$ to $\mathrm{PH}<2$ and filtered using $0.45 \mu \mathrm{m}$ nylon filters to estimate the presence of $\mathrm{Cr}, \mathrm{Ni}, \mathrm{Cu}, \mathrm{Zn}, \mathrm{As}, \mathrm{Cd}$ and $\mathrm{Pb}$ [11]. The feed samples were grinded with a mortar and pestle to screen through a 100-mesh nylon sieve. Each feed sample of $0.5 \mathrm{~g}$ was digested with $10 \mathrm{~mL} \mathrm{HNO}_{3}$ to determine the target metals [12]. In the case of sediment, it was air-dried, ground in an agate mortar and passed through a 100-mesh nylon sieve. Sediment samples $(0.1 \mathrm{~g})$ were digested with the mixture of $3 \mathrm{~mL} \mathrm{HNO}_{3}, 1 \mathrm{~mL} \mathrm{HCL}$ and $1 \mathrm{~mL} \mathrm{HF}$ to measure the metal concentrations [13]. Fish samples were cleaned with deionized water and measured the biometric data (fish length and fish weight) (Table S1). The fish samples were dissected using a scalpel to separate the tissues (including the muscle, skin, bladder, gill, heart, kidney and liver). The separated tissues were washed, freeze-dried at a freeze dryer (Christ ALPHA 1 - 2 LD plus, Germany) for 3 - $4 \mathrm{~d}$ and then uniformly ground into powder until the metal concentration was measured. Ultra pure nitric acid $(10 \mathrm{~mL})$ was added for every dry tissue sample of $0.5 \mathrm{~g}$ to analysis the metals [12]. A 350X inductively coupled plasma mass spectrometer (Perkin Elmer; Waltham, MA, USA) was applied to analysis the studied metals in digested solutions.

\subsection{QA/QC}

All glassware and polyethylene bottles used in this study were pre-soaked with $10 \% \mathrm{HNO}_{3}$ for $24 \mathrm{~h}$, rinsed with ultrapure water and then air dried before use. Three samples including one procedural bank, one matrix spike sample and one bank spike sample were analyzed along with every batch digestion samples (10 samples). The recoveries of $\mathrm{Cr}, \mathrm{Ni}, \mathrm{Cu}, \mathrm{Zn}, \mathrm{As}$, $\mathrm{Cd}$ and $\mathrm{Pb}$ were $94 \% \pm 20 \%, 92 \%$ $\pm 3 \%, 86 \% \pm 2 \%, 91 \% \pm 15 \%, 92 \% \pm 2 \%, 87 \% \pm 1 \%$ and $76 \% \pm 1 \%$ in matrix spike water samples. The standard reference material (GBW10050; Chinese Academy of Geological Sciences) was used to guarantee the determination accuracy for feed and fish samples. The recoveries were $80 \% \pm 20 \%$ for $\mathrm{Cr}, 86 \% \pm$ $11 \%$ for $\mathrm{Ni}, 90 \% \pm 15 \%$ for $\mathrm{Cu}, 97 \% \pm 8 \%$ for $\mathrm{Zn}, 86 \% \pm 4 \%$ for As, $81 \% \pm 10 \%$ for $\mathrm{Cd}$ and $86 \% \pm 12 \%$ for $\mathrm{Pb}$. Recovery tests for the sediment standard reference (GBW07312; Chinese Academy of Geological Sciences) scored 80\% $\pm 10 \%$ for $\mathrm{Cr}, 96 \% \pm 6 \%$ for $\mathrm{Ni}, 102 \% \pm 15 \%$ for $\mathrm{Cu}, 98 \% \pm 6 \%$ for $\mathrm{Zn}, 99 \% \pm 12 \%$ for As, $118 \% \pm 14 \%$ for $\mathrm{Cd}$ and $99 \% \pm 8 \%$ for $\mathrm{Pb}$.

\subsection{Data Analysis}

The concentrations of heavy metals were presented on a dry weight ( $\mathrm{dw}$ ) as $\mathrm{mg} \cdot \mathrm{kg}^{-1}$. For comparison, the wet weight (ww) converted to dw with a conversion rate of $20 \%$ (assuming water content of $80 \%$ ) [14]. Statistical analysis was performed using SPSS 22.0 software and EXCEL 2007. The sampling map was drawn by ArcMap 10.2. The Geoaccumulation index $\left(I_{\text {geo }}\right)$, metal pollution index (MPI), bioaccumulation factor (BCF), biota-sediment accumulation factor (BSAF) and the metal concentrations in tissues were performed using SigmaPlot 10.0 . 


\subsection{Risk Assessment Methods}

The geoaccumulation index $\left(I_{\text {geo }}\right)$ was applied to assess the concentrations of heavy metals in sediments [15] and expressed as Equation (1):

$$
I_{\text {geo }}=\log _{2} \frac{C_{\mathrm{n}}}{1.5 \times B_{\mathrm{n}}}
$$

where $C_{\mathrm{n}}$ is the measured content of metal $\mathrm{n}$ in sediments, $B_{\mathrm{n}}$ is the background value of metal $\mathrm{n}$ in sediments. The constant 1.5 performs the potential variation about the baseline date caused by lithogenic effects [15]. The geochemical background values in Guanddong Province were $50.5 \mathrm{mg} \cdot \mathrm{kg}^{-1}$ for $\mathrm{Cr}, 14.4 \mathrm{mg} \cdot \mathrm{kg}^{-1}$ for $\mathrm{Ni}, 17 \mathrm{mg} \cdot \mathrm{kg}^{-1}$ for $\mathrm{Cu}, 47.3 \mathrm{mg} \cdot \mathrm{kg}^{-1}$ for $\mathrm{Zn}, 8.9 \mathrm{mg} \cdot \mathrm{kg}^{-1}$ for As, $0.056 \mathrm{mg} \cdot \mathrm{kg}^{-1}$ for $\mathrm{Cd}$ and $36 \mathrm{mg} \cdot \mathrm{kg}^{-1}$ for $\mathrm{Pb}$ [16]. The lists of 7 grades of $I_{\text {geo }}$ are shown in Table S2.

The Potential ecological risk index was established by [17] to assess the heavy metals ecological risks in sediment $\left(E_{i}\right)$ and comprehensive heavy metals ecological risks in sediment (RI), which could be calculated with the following Equations (2)-(3):

$$
\begin{gathered}
E_{i}=T_{i} \times\left(C_{i} \times S_{i}\right) \\
\mathrm{RI}=\sum_{i=1}^{7} E_{i}
\end{gathered}
$$

where $C_{i}$ and $S_{i}$ are the measured and background concentrations of metal $i$, as well as $T_{i}$ is the toxicity factor of metal $i(\mathrm{Cr}=2, \mathrm{Ni}=\mathrm{Cu}=\mathrm{Pb}=5, \mathrm{Zn}=1, \mathrm{As}=$ 10 and $\mathrm{Cd}=30)$ [18]. The $E_{i}$ and RI classification are presented in Table S3.

The metal pollution index (MPI) was used to compare the metal concentration in different tissues [19] and Equation (4) was:

$$
\text { MPI }=\left(C_{1} \times C_{2} \times \cdots \times C_{i}\right)^{\frac{1}{i}}
$$

where $C_{i}$ are the average concentrations of metal $i$ in tissues $\left(\mathrm{dw}, \mathrm{mg} \cdot \mathrm{kg}^{-1}\right)$.

Bioaccumulation factor (BCF) is to assess by the ratio between metal concentration in the fish organs and those in the water, while the biota-sediment accumulation (BSAF) is to assess by the ratio between metal concentration in the fish organs and those in the sediment [10]. The calculated Equations (5)-(6) are:

$$
\begin{gathered}
\mathrm{BSAF}=C_{\text {fish }} / C_{\text {sediment }} \\
\mathrm{BCF}=C_{\text {fish }} / C_{\text {water }}
\end{gathered}
$$

where $C_{\text {fish }}, C_{\text {water }}$ and $C_{\text {sediment }}$ are the metal concentration in the fish tissue, water and sediment. The grades of $\mathrm{BCF}$ values are: less probability of accumulation (BCF < 1000); bioaccumulative ( $1000<\mathrm{BCF}<5000)$; highly bioaccumulative (5000 $<\mathrm{BCF}$ ). As for BASF, if the value $>1$, it suggests metal in fish tissue can accumulate from the sediment.

Health risk of metal in fishes was assessed by estimation of daily intake (EDI), target hazard quotient (THQ), hazard index (HI) and carcinogenic risk (CR), which were calculated with the following Equations (7)-(10) [20] [21] [22] [23]. 


$$
\begin{gathered}
\mathrm{EDI}=\frac{\mathrm{CN} \times \mathrm{DC}}{\mathrm{BW}} \\
\mathrm{THQ}=\frac{\mathrm{CN} \times \mathrm{DC} \times \mathrm{EF} \times \mathrm{ED}}{\mathrm{BW} \times \mathrm{AT} \times \mathrm{RfD}} \\
\mathrm{HI}=\sum_{i=1}^{7} \mathrm{THQ} \\
\mathrm{CR}=\frac{\mathrm{CN} \times \mathrm{DC} \times \mathrm{EF} \times \mathrm{ED} \times \mathrm{CSF} \times 10^{-3}}{\mathrm{BW} \times \mathrm{AT}}
\end{gathered}
$$

where $\mathrm{CN}$ is the metal concentration in tissues (ww, $\mathrm{mg} \cdot \mathrm{kg}^{-1}$ ); DC is the daily ingestion rate $\left(51.8\right.$ g.person ${ }^{-1} \cdot$ day $\left.^{-1}\right)$ [24]; BW is the body weight $(60 \mathrm{~kg})$; EF is exposure frequency (365 days year $\left.{ }^{-1}\right)$; ED is the exposure duration (70 years); AT is the average exposure time for non carcinogens (365 days $\times 70$ year) [19]; $\mathrm{RfD}$ is the oral reference dose $(\mathrm{Cr}, \mathrm{Ni}, \mathrm{Cu}, \mathrm{Zn}, \mathrm{As}, \mathrm{Cd}$ and $\mathrm{Pb}$ are 5, 20, 40, 300, $0.3,1$ and $1.5 \mu \mathrm{g} \cdot \mathrm{kg}^{-1} \cdot \mathrm{day}^{-1}$ ) [25]; CSF is oral slope factor of carcinogens for As $\left(1.5 \mathrm{mg} \cdot \mathrm{kg}^{-1} \cdot \mathrm{day}^{-1}\right)$ and $\mathrm{Cd}\left(6.3 \mathrm{mg} \cdot \mathrm{kg}^{-1} \cdot\right.$ day $\left.^{-1}\right)[20]$.

\section{Results and Discussion}

\subsection{Metal Concentrations in the Water}

The heavy metal concentrations in the pond water during a complete breeding cycle are given in Table S4. The mean metals concentrations were in the order of $\mathrm{Zn}>\mathrm{Cu}>\mathrm{As}>\mathrm{Ni}>\mathrm{Pb}>\mathrm{Cr}>\mathrm{Cd}$. The concentration of $\mathrm{Zn}(48.7 \pm 21.9$ $\left.\mu \mathrm{g} \cdot \mathrm{L}^{-1}\right)$ and $\mathrm{Cu}\left(5.72 \pm 4.71 \mu \mathrm{g} \cdot \mathrm{L}^{-1}\right)$ in the water were relatively high, which was consistent with the result from Wen-Rui Tang River [26]. Additionally, the Zn and $\mathrm{Cu}$ concentrations in this pond water were higher than the Pearl River [27], which might due to the input of enriched $\mathrm{Zn}$ and $\mathrm{Cu}$ feeds (Table S5). The concentrations of heavy metals in the pond water were increased in June 2018 than in December 2017, which could be explained that the fish feeds were the major sources of metals to aquaculture [5]. The higher metal concentrations were observed in March 2018, which might be related to the increased feed remains in the water. In comparison to the fisheries standard of China [28], concentrations of metals in the pond water did not exceed the permissible values. The result indicated that the pond water quality was suitable for farming. According to the classification criteria of contamination degree (CD) [29] which was used to assess the heavy metal pollution in water, the calculated results showed that heavy metals in the water showed low pollution $(\mathrm{CD}<6)$.

\subsection{Sediment Metals Concentrations}

The metals concentrations analyzed in the fish pond sediments are presented in Table S6. There were no significant differences $(\mathrm{P}>0.05)$ among the heavy metals during the complete breeding cycle. The average metals concentrations in the pond sediments decreased in the order of $\mathrm{Zn}>\mathrm{Cr}>\mathrm{Pb}>\mathrm{As}>\mathrm{Cu}>\mathrm{Ni}>\mathrm{Cd}$. The concentrations of $\mathrm{Zn}, \mathrm{Cr}, \mathrm{As}, \mathrm{Cu}, \mathrm{Ni}$ and $\mathrm{Cd}$ were approximately 2.7, 1.34, 
3.4, 2, 2 and 6.25 times higher than that of the background values [16], indicating these metal pollutions came from anthropogenic activities. While the concentration of $\mathrm{Pb}$ was comparable to the background value, implying the $\mathrm{Pb}$ was mainly from the earth crust.

\subsection{Occurrence of Heavy Meals in Fish}

The concentrations of heavy metals in tissue organs during a complete breeding cycle are depicted in Table S7 and Figure 2. Average values of heavy metals in the muscle are shown in Table 1. Zinc had the highest concentration in tissue organs, followed by $\mathrm{Cu}, \mathrm{Cr}, \mathrm{Ni}, \mathrm{Pb}$, As and $\mathrm{Cd}$.

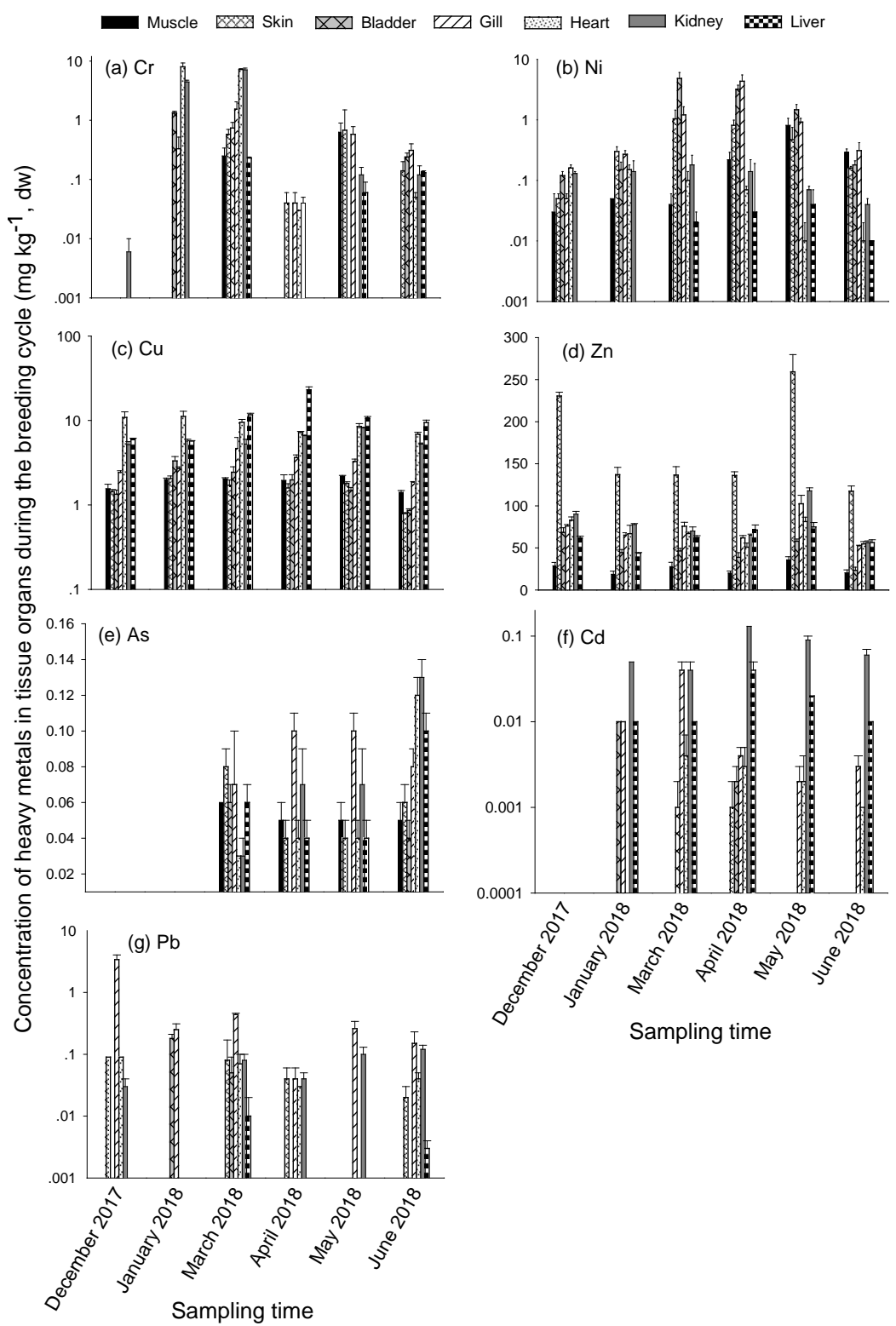

Figure 2. The distribution of $\mathrm{Cr}, \mathrm{Ni}, \mathrm{Cu}, \mathrm{Zn}, \mathrm{As}, \mathrm{Cd}$ and $\mathrm{Pb}$ concentrations in tissue organs from December 2017 to June 2018 collected in the pond of gull island in the Pearl River Delta, China. 
Table 1. Mean metal concentrations in fish from the present and previous studies (dw, $\left.\mathrm{mg} \cdot \mathrm{kg}^{-1}\right)$.

\begin{tabular}{ccccccccc}
\hline Location & $\mathrm{Cr}$ & $\mathrm{Ni}$ & $\mathrm{Cu}$ & $\mathrm{Zn}$ & $\mathrm{As}$ & $\mathrm{Cd}$ & $\mathrm{Pb}$ & References \\
\hline $\begin{array}{c}\text { Grass carp in the } \\
\text { Pearl River Delta }\end{array}$ & 0.15 & 0.24 & 1.86 & 25.2 & 0.04 & - & - & $\begin{array}{c}\text { The present } \\
\text { study }\end{array}$ \\
$\begin{array}{c}\text { Grunt in Persian Gulf } \\
\text { Mullus barbatus in }\end{array}$ & 11.2 & 14.2 & 0.04 & 0.8 & 0.2 & 0.4 & 1.8 & {$[32]$} \\
$\begin{array}{c}\text { Trabzon, Turkey } \\
\text { C. mrigala in River } \\
\text { Ganga, India }\end{array}$ & 0.03 & 0.25 & 0.26 & 1.65 & - & 0.004 & 0.04 & {$[33]$} \\
$\begin{array}{c}\text { Barramudi in Pulau } \\
\text { Ketam, Malaysia }\end{array}$ & 0.62 & -0.12 & 0.50 & 6.50 & 1.69 & 0.01 & 0.17 & {$[35]$} \\
$\begin{array}{c}\text { S. aurata W in } \\
\text { Mediterranean }\end{array}$ & 0.004 & - & 0.04 & 0.71 & 1.10 & 0.0004 & - & {$[19]$} \\
$\begin{array}{c}\text { Trigla lyrain Northern } \\
\text { Aegean Sea }\end{array}$ & 0.01 & 0.14 & 0.27 & 0.90 & - & 0.01 & 0.06 & {$[36]$} \\
$\begin{array}{c}\text { Crucian carp in } \\
\text { Chengdu, China }\end{array}$ & 6.21 & 1.18 & 2.77 & 69.1 & 0.38 & 0.01 & 0.38 & {$[10]$} \\
$\begin{array}{c}\text { Fishes in Chaohu Lake, } \\
\text { China }\end{array}$ & 0.18 & - & 0.33 & 8.51 & 0.10 & 0.001 & 0.03 & {$[37]$} \\
$\begin{array}{c}\text { Fishes in Northeast } \\
\text { China }\end{array}$ & 0.01 & 0.01 & 0.03 & 1.59 & 0.01 & 0.0002 & 0.007 & {$[38]$} \\
$\begin{array}{c}\text { Threshold } \\
\text { Can }\end{array}$ & $0.4^{\mathrm{a}}$ & - & $8^{\mathrm{b}}$ & $20^{\mathrm{c}}$ & $1.2^{\mathrm{b}}$ & $0.2^{\mathrm{a}}$ & $0.1^{\mathrm{a}}$ & \\
\hline
\end{tabular}

${ }^{\mathrm{a}}$ China National Standards (GB 2762-2017) [45]. ${ }^{\mathrm{b} E u r o p e a n ~ C o m m i s s i o n ~[41] . ~}{ }^{\mathrm{c} F o o d}$ and Agriculture Organization, World Health Organization [31]. ${ }^{\mathrm{d}}$ Means date are not available.

Zinc is the essential metal to promote metabolism and its shortage can result in some adverse influences, i.e. retarded growth, dysfunction of the immune system and appetite loss [30]. The $\mathrm{Zn}$ concentration was the highest compared to target metals analyzed in different tissue. During the breeding cycle, the highest $\mathrm{Zn}$ concentration $\left(259 \pm 20.5 \mathrm{mg} \cdot \mathrm{kg}^{-1}, \mathrm{dw}\right)$ was observed in the skin (May 2018 ) and the lowest $\mathrm{Zn}$ value $\left(18.6 \pm 3.79 \mathrm{mg} \cdot \mathrm{kg}^{-1}, \mathrm{dw}\right)$ was found in the muscle (January 2018). The accumulation sequence of mean $\mathrm{Zn}$ concentrations in all the organs with an order is skin $>$ kidney $>$ gill $>$ heart $>$ liver $>$ bladder $>$ muscle. The skin is the main organ which accumulated higher $\mathrm{Zn}$ concentration compared to other target organs. Skin is the organ directly contact with water, $\mathrm{Zn}$ had the highest concentration in the water compared to other target metals could cause the higher $\mathrm{Zn}$ accumulation in the skin. Interestedly, relatively higher $\mathrm{Zn}$ concentrations in all the organs were observed in May 2018, and the concentration of $\mathrm{Zn}$ in June 2018 was lower than the background value in organs in December 2017. Since Aril 2018, the intake of feeds increased with the temperature increasing. Subsequently, the rainfall started to increase since May 2018, this might cause the decrease in $\mathrm{Zn}$ concentration in organs in June 2018. The mean $\mathrm{Zn}$ concentration in the muscle was higher than the acceptable limit (20 $\mathrm{mg} \cdot \mathrm{kg}^{-1}, \mathrm{dw}$ ) proposed by World Health Organization [31]. Moreover, the aver- 
age $\mathrm{Zn}$ concentration in this study was higher than those reported studies [19] [32]-[38], but lower than this reported study [10].

Copper is the essential metal to form the hemoglobin and some requisite enzymes, but excess intake of $\mathrm{Cu}$ can alter the liver and kidney function [39]. The lowest $\mathrm{Cu}$ concentration was observed in the skin $\left(0.79 \pm 0.02 \mathrm{mg} \cdot \mathrm{kg}^{-1}, \mathrm{dw}\right)$ in June 2018, and the highest concentration of $\mathrm{Cu}$ was found in the liver $(23.1 \pm$ $1.93 \mathrm{mg} \cdot \mathrm{kg}^{-1}, \mathrm{dw}$ ) in April 2018. The mean concentrations of $\mathrm{Cu}$ in organs were in the sequence of: liver $>$ heart $>$ kidney $>$ gill $>$ bladder $>$ muscle $>$ skin. The highest $\mathrm{Cu}$ value was found in the liver which was in agreement with the study [40]. The acceptable limit of $8 \mathrm{mg} \cdot \mathrm{kg}^{-1} \mathrm{dw}$ for $\mathrm{Cu}$ was developed by European Commission [41]. It was worth noting that the mean $\mathrm{Cu}$ concentration in the muscle was far higher than those recorded values [19] [32]-[38], but lower than the accorded value [10].

Chromium is regarded as being involved in the metabolism of carbohydrates and lipids [42]. If the intake of $\mathrm{Cr}$ is not enough, the risks of cardiovascular diseases and diabetes will be increased [43]. The highest $\mathrm{Cr}$ level was detected in the heart $\left(8.01 \pm 1.28 \mathrm{mg} \cdot \mathrm{kg}^{-1}, \mathrm{dw}\right)$ in January 2018 , and the lowest level was detected in the kidney $\left(0.01 \pm 0.004 \mathrm{mg} \cdot \mathrm{kg}^{-1}, \mathrm{dw}\right)$ in December 2017. The average Cr concentration in organs was arranged in the following order: heart > kidney $>$ gill $>$ bladder $>$ skin $>$ muscle $>$ liver. The concentrations of $\mathrm{Cr}$ in organs in March 2018 were higher than in June 2018, probably because the absorption rate of young fish was relatively high but the body burden of $\mathrm{Cr}$ was declined with age due to rapid elimination [44]. The average content of $\mathrm{Cr}$ in the muscle did not exceed the permissible value established by China National Standards (GB 2762-2017) [45]. Furthermore, the mean Cr content in the muscle was lower than the values reported from the Persian Gulf $\left(11.2 \mathrm{mg} \cdot \mathrm{kg}^{-1}, \mathrm{dw}\right)$ [32], Pulau Ketam, Malaysia (0.62 mg. $\mathrm{kg}^{-1}, \mathrm{dw}$ ) [35] and Chengdu, China (6.21 mg. $\left.\mathrm{kg}^{-1}, \mathrm{dw}\right)$ [10], but higher than those reported values from the Trabzon, Turkey $(0.03$ $\left.\mathrm{mg} \cdot \mathrm{kg}^{-1}, \mathrm{dw}\right)$ [33], River Ganga, India (0.07 mg. $\left.\mathrm{kg}^{-1}, \mathrm{dw}\right)$ [34], Mediterranean (0.004 mg. $\left.\mathrm{kg}^{-1}, \mathrm{dw}\right)$ [19], Northern Aegean Sea (0.01 mg.kg-1, dw) [36] and Northeast China $\left(0.01 \mathrm{mg} \cdot \mathrm{kg}^{-1}, \mathrm{dw}\right)$ [38]. However, the mean Cr content in the muscle was comparable to the value reported from the Chao lake, China (0.18 $\mathrm{mg} \cdot \mathrm{kg}^{-1}, \mathrm{dw}$ ) [37].

Nickel can cause adverse health effects to pulmonary, e.g., fibrosis, tumours and lung inflammation [46]. In the present study, the highest amount of $\mathrm{Ni}$ was found in the bladder $\left(4.83 \pm 1.21 \mathrm{mg} \cdot \mathrm{kg}^{-1}, \mathrm{dw}\right)$ in March 2018 and the lowest amount of Ni was observed in the liver $\left(0.01 \pm 0.004 \mathrm{mg} \cdot \mathrm{kg}^{-1}, \mathrm{dw}\right)$ in June 2018. The order of mean $\mathrm{Ni}$ concentration in organs from large to small was as follows: bladder $>$ gill $>$ skin $>$ muscle $>$ kidney $>$ heart $>$ liver. The observed mean value of $\mathrm{Ni}\left(0.24 \mathrm{mg} \cdot \mathrm{kg}^{-1}, \mathrm{dw}\right)$ in fish muscles was higher than those observed from Pulau Ketam, Malaysia $\left(0.12 \mathrm{mg} \cdot \mathrm{kg}^{-1}, \mathrm{dw}\right)$ [35], Northern Aegean Sea (0.14 $\left.\mathrm{mg} \cdot \mathrm{kg}^{-1}, \mathrm{dw}\right)$ [36] and Northeast China $\left(0.01 \mathrm{mg} \cdot \mathrm{kg}^{-1}, \mathrm{dw}\right)$ [38], but lower than those values reported for Ni from the Persian Gulf (14.2 mg. $\left.\mathrm{kg}^{-1}, \mathrm{dw}\right)$ [32] and 
Chengdu, China (1.18 mg. $\mathrm{kg}^{-1}, \mathrm{dw}$ ) [10]. However, the mean Ni concentration was comparable to the value from the Trabzon, Turkey $\left(0.25 \mathrm{mg} \cdot \mathrm{kg}^{-1}, \mathrm{dw}\right)$ [33].

Lead is a non-essential element and can cause adverse health effects (neurotoxicity and nephrotoxicity) [47]. The highest $\mathrm{Pb}$ content was detected in the gill $\left(1.40 \pm 0.14 \mathrm{mg} \cdot \mathrm{kg}^{-1}, \mathrm{dw}\right)$ in December 2017 , while the lowest content was detected in the liver $\left(0.003 \pm 0.001 \mathrm{mg} \cdot \mathrm{kg}^{-1}, \mathrm{dw}\right)$ in June 2018 . There were significant differences in $\mathrm{Pb}$ concentrations among different fish organs $(\mathrm{P}<0.05)$. No $\mathrm{Pb}$ concentrations were detected in the muscle. The following decreasing order of mean $\mathrm{Pb}$ content in organs was found: gill $>$ kidney $>$ heart $\approx$ bladder $\approx$ skin $>$ liver. The average $\mathrm{Pb}$ concentration in the muscle did not exceed the maximum levels set by [45], as well as lower than those reported studies [10] [32]-[38].

Arsenic is an ubiquitous in the environment and may be potentially a toxic metal. The highest concentration of As was detected in the kidney $(0.13 \pm 0.01$ $\mathrm{mg} \cdot \mathrm{kg}^{-1}, \mathrm{dw}$ ) in June 2018, whereas the lowest concentration was detected in the bladder $\left(0.02 \pm 0.01 \mathrm{mg} \cdot \mathrm{kg}^{-1}, \mathrm{dw}\right)$ in April 2018. The As concentrations were not detected in all the target organs from December 2017 to January 2018. In addition, the distribution of As in each organ is relatively balanced compared to other target metals. The mean As concentrations in organs could be sequenced as follows: gill $\approx$ kidney $>$ muscle $\approx$ skin $\approx$ heart $\approx$ liver $>$ bladder. The mean As concentration in the muscle was far lower than the regulated value by [41]. Compared with other previous values, the mean concentration of As was lower than [10] [19] [32] [35] [37], but higher than [38].

Cadmium is deemed as an element with chronic toxicity. The concentrations of Cd were the lowest in organs compared to other target metals. The highest Cd concentration was recorded in the kidney $\left(0.13 \pm 0.003 \mathrm{mg} \cdot \mathrm{kg}^{-1}, \mathrm{dw}\right)$ in April 2018 , and the lowest value was recorded in the heart $\left(0.001 \pm 0.0002 \mathrm{mg} \cdot \mathrm{kg}^{-1}\right.$, dw) in June 2018. In December 2017, As concentrations were not detected in any organs. In the case of fish organs, there were not detected in the muscle and skin (except the April 2018) from December 2017 to June 2018. The average Cd concentrations were observed in the order of kidney $>$ liver $>$ gill $>$ heart $\approx$ bladder $>$ skin. The average $\mathrm{Cd}$ concentration was lower than the maximum level set by [45], as well as those reported studies [10] [19] [32]-[38].

\subsection{Assessment of Sediment Quality}

Table S8 shows the calculated values of $I_{\text {geo }}, E_{i}$ and RI for garget metals in the pond sediment in PRD. The average $I_{\text {geo }}$ of heavy metals were ranked in the order of $3>\mathrm{Cd}>2>\mathrm{As}>1>\mathrm{Zn}>\mathrm{Ni}>\mathrm{Cu}>0>\mathrm{Cr}>\mathrm{Pb}$. Based on the criteria of sediment $I_{\text {geo }}$, Cd was moderate to heavily contaminated; As was moderately contaminated; $\mathrm{Zn}, \mathrm{Ni}$ and $\mathrm{Cu}$ were uncontaminated to moderately contaminated; $\mathrm{Cr}$ and $\mathrm{Pb}$ were uncontaminated. The mean values of $E_{\mathrm{i}}$ for $\mathrm{As}, \mathrm{Ni}, \mathrm{Cu}$, $\mathrm{Pb}, \mathrm{Cr}$ and $\mathrm{Zn}$ did not exceed 40, implying low risk caused by these metals in the pond sediment. Moreover, Cd contributed high risk in the sediment with the value between 160 and 320. According to the RI values, moderate risk $(150<\mathrm{RI}$ 
$<300)$ were presented by these heavy metals in this study area.

\subsection{Metal Pollution Index}

The MPI can be visually used to indicate the degree of metal pollution in fish tissues. The calculated MPI results in different tissues during a complete breeding cycle are shown in Figure 3. The highest MPI value was observed in the gill (1.00), while the lowest value found in the liver (0.004). It was worth noting that the highest and lowest MPI values in all the tissues occurred in March 2018 and December 2017, except that the muscle showed the highest MPI value in May 2018 and the skin found the lowest MPI value in January 2018. The average MPI value in tissues was as follows: gill $(0.39)>$ kidney $(0.34)>$ heart $(0.15)>$ bladder $(0.13)>\operatorname{skin}(0.11)>$ liver $(0.10)>$ muscle $(0.03)$. The gill and kidney had higher metal pollution compared with other target tissues, which was consistent with the previous study [25]. One way for the metal to enter the fish is through the breath of the gill, and the mucus in the gill can easily absorb metal ions or metal-containing suspensions, etc., and the kidney is the detoxification center of active metabolism of the organism, so the MPI values of the gill and kidney will be higher than other tissues.

\subsection{Bioaccumulation Factor and Biota-Sediment Accumulation of Heavy Metals in Organisms}

The BCF is used to assess the ability of the aquatic organism to accumulate metals from the water. If $\mathrm{BCF}>1000$, it implies that the organism has a potential to accumulate the metals, and vice versa. The calculated $\mathrm{BCF}$ values are presented in Figure 4(a). The highest BCF value was found for Cd (in the kidney), while the lowest value was observed for As (in the bladder). The BCF values of metals in the grasp carp were generally in the order of $\mathrm{Zn}>\mathrm{Cu}>\mathrm{Cd}>\mathrm{Cr}>\mathrm{Ni}>\mathrm{Pb}>$ As. The BCF values of $\mathrm{Cu}$ and $\mathrm{Zn}$ (essential metals) were higher than $\mathrm{Cr}, \mathrm{Ni}, \mathrm{As}$, $\mathrm{Cd}$ and $\mathrm{Pb}$ (non-essential elements), implying that a more important transfer of essential elements than non-essential elements which was inconsistent with previous research [48].

The BSAF is depicted to evaluate the ability of the aquatic organism to accumulate metals from the sediment and the results are shown in Figure 4(b). If BASF $>1$, it reflects that the organisms can probably accumulate metals. Among all the metals, only $\mathrm{Zn}$ had the value of BASF $>1$ in the skin, this result indicated that the skin could accumulate $\mathrm{Zn}$ from the sediment. Probably because grass carp mainly live in the lower layer of the water environment enriched with a higher $\mathrm{Zn}$ concentration.

\subsection{Health Risk Assessment}

The values of EDI for target metals are shown in Table S9. The EDI of all the metals during the breeding cycle was far less than the PTDI, indicating that the exposure risk of heavy metals through the fish consumption within the safe range. 


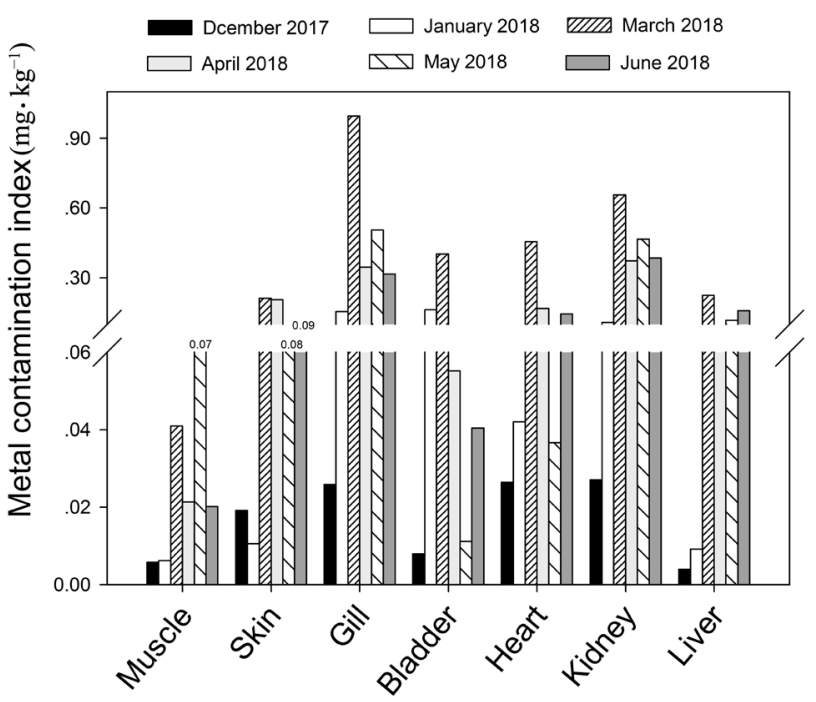

Figure 3. The distribution of metal pollution index in various organs from December 2017 to June 2018 captured in the pond of gull island in the Pearl River Delta, China.
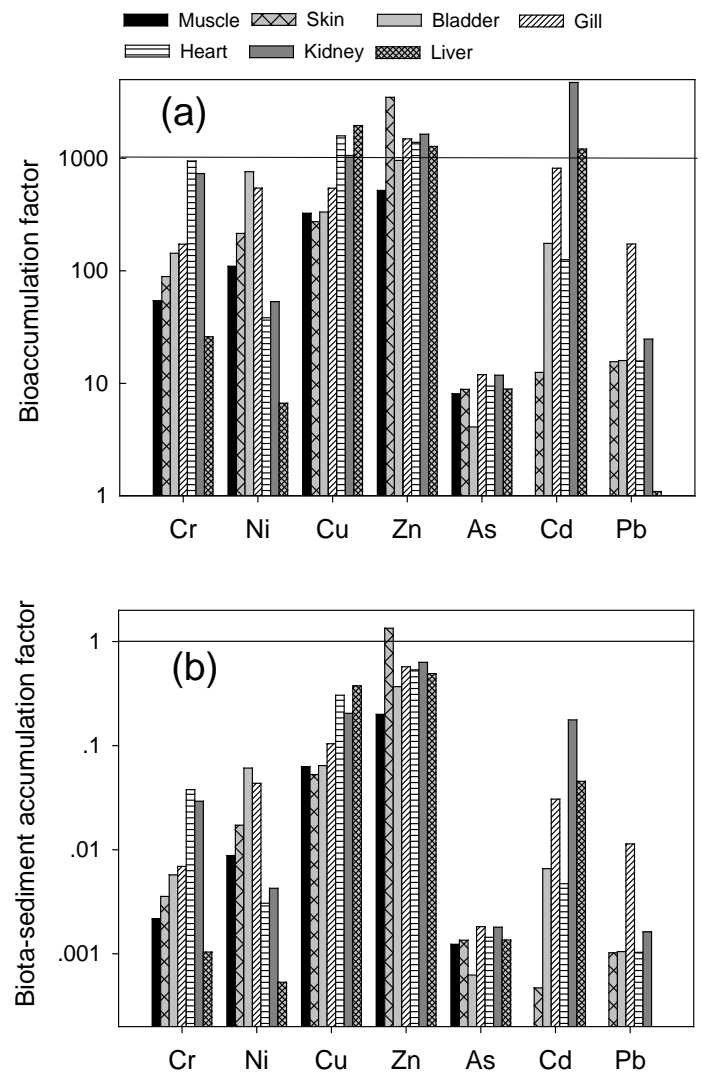

Figure 4. The values of bioaccumulation factor and biota-sediment accumulation in different organs collected in the pond of gull island in the Pearl River Delta, China.

The calculated values of THQ, HI and CR are given in Table S10. The highest value of THQ was found in May 2018, and the THQ of all the target metals was 
less than 1 during the breeding cycle, which demonstrated that the non-carcinogenic health risks associated with intake of single metal through the consumption of grasp carps. Considering that human exposure to multiple heavy metals may produce synergistic or interactive effects, the individual THQ of the seven heavy metals are added to obtain the HI. The results showed that the maximum HI value $(<1)$ during the breeding cycle was obtained in May 2018, which indicated that there was non-carcinogenic risk associated with intake of multiple metals through the consumption of grasp carps. In general, when the $\mathrm{CR}$ value is less than $10^{-6}$, it is considered that the carcinogenic risk can be negligible; when the $\mathrm{CR}$ value is higher than $10^{-4}$, the carcinogenic risk is unacceptable; when the value of $\mathrm{CR}$ is between $10^{-6}$ and $10^{-4}$, the carcinogenic risk is considered to be acceptable [49]. In Table S10, the Cd CR values were less than $10^{-6}$, implying that the carcinogenic risk caused by $\mathrm{Cd}$ could be negligible. The As $\mathrm{CR}$ values were less than $10^{-6}$ from December 2017 to January 2018, and the As CR values were between $10^{-6}$ to $10^{-4}$ from March and June of 2018, this results showed that carcinogenic risk could be negligible in December 2017 and January 2018, whereas the carcinogenic risk was considered to be acceptable from the rest sampling month. In summary, the consumption of grass carp during the complete breeding cycle caused non-cancer risk.

\section{Conclusion}

The distribution of metals in organs varied differently; the concentrations of heavy metals in the internal organs were higher than the muscle. In addition, $\mathrm{Cu}$ and $\mathrm{Zn}$ were more easily accumulated in the organisms compared with other target metals. The higher metals pollution was found in March 2018 in all the tissues, with the exception of muscle contributed to more metals pollution in May 2018. The heavy metals (especially for $\mathrm{Zn}$ ) probably accumulated from the water due to the life behavior of grass carp. Overall, the grass carp obtained in the pond of gull island was safe for edible. Carrying out such a comprehensive study in a typical breeding area can be used as a good model for environmental health risk assessment, and then provide some useful information for environmental pollution control.

\section{Acknowledgements}

The present study was financially supported by the National Natural Science Foundation of Guangdong Province (No. 2015B020237006) and the special S\&T project on treatment and control of water pollution (No. 2017ZX07301006004). We thank for Yun-Qi Chen, Rui Che and Jing Liu for field and laboratory support.

\section{Capsule}

Copper and $\mathrm{Zn}$ were more easily accumulated in the organisms compared with other target metals. 


\section{Conflicts of Interest}

The authors declare no competing financial interest.

\section{References}

[1] Cheung, K.C., Leung, H.M. and Wong, M.H. (2008) Metal Concentrations of Common Freshwater and Marine Fish from the Pearl River Delta, South China. Archives of Environmental Contamination and Toxicology, 54, 705-715. https://doi.org/10.1007/s00244-007-9064-7

[2] Ye, Z., Chen, J., Gao, L., Liang, Z., Li, S., Li, R., Jin, G., Shimizu, Y., Onodera, S.-I., Saito, M. and Gopalakrishnan, G. (2020) Pb-210 Dating to Investigate the Historical Variations and Identification of Different Sources of Heavy Metal Pollution in Sediments of the Pearl River Estuary, Southern China. Marine Pollution Bulletin, 150, 110670. https://doi.org/10.1016/j.marpolbul.2019.110670

[3] Zhou, H.Y., Peng, X.T. and Pan, J.M. (2004) Distribution, Source and Enrichment of Some Chemical Elements in Sediments of the Pearl River Estuary, China. Continental Shelf Research, 24, 1857-1875. https://doi.org/10.1016/j.csr.2004.06.012

[4] Cheng, Z., Man, Y.B., Nie, X.P. and Wong, M.H. (2013) Trophic Relationships and Health Risk Assessments of Trace Metals in the Aquaculture Pond Ecosystem of Pearl River Delta, China. Chemosphere, 90, 2142-2148. https://doi.org/10.1016/j.chemosphere.2012.11.017

[5] Lacerda, L.D., Soares, T.M., Costa, B.G.B. and Godoy, M.D.P. (2011) Mercury Emission Factors from Intensive Shrimp Aquaculture and Their Relative Importance to the Jaguaribe River Estuary, NE Brazil. Bulletin of Environmental Contamination and Toxicology, 87, 657-661. https://doi.org/10.1007/s00128-011-0399-4

[6] Pal, D. and Maiti, S.K. (2018) Seasonal Variation of Heavy Metals in Water, Sediment, and Highly Consumed Cultured Fish (Labeo rohita and Labeo bata) and Potential Health Risk Assessment in Aquaculture Pond of the Coal City, Dhanbad (India). Environmental Science and Pollution Research, 25, 12464-12480. https://doi.org/10.1007/s11356-018-1424-5

[7] Qiu, Y.-W., Lin, D., Liu, J.-Q. and Zeng, E.Y. (2011) Bioaccumulation of Trace Metals in Farmed Fish from South China and Potential Risk Assessment. Ecotoxicology and Environmental Safety, 74, 284-293.

https://doi.org/10.1016/j.ecoenv.2010.10.008

[8] Ip, C.C.M., Li, X.D., Zhang, G., Wong, C.S.C. and Zhang, W.L. (2005) Heavy Metal and $\mathrm{Pb}$ Isotopic Compositions of Aquatic Organisms in the Pearl River Estuary, South China. Environmental Pollution, 138, 494-504.

https://doi.org/10.1016/j.envpol.2005.04.016

[9] Leung, H.M., Leung, A.O.W., Wang, H.S., Ma, K.K., Liang, Y., Ho, K.C., Cheung, K.C., Tohidi, F. and Yung, K.K.L. (2014) Assessment of Heavy Metals/Metalloid (As, Pb, Cd, Ni, Zn, Cr, Cu, Mn) Concentrations in Edible Fish Species Tissue in the Pearl River Delta (PRD), China. Marine Pollution Bulletin, 78, 235-245. https://doi.org/10.1016/j.marpolbul.2013.10.028

[10] Liu, X., Jiang, J., Yan, Y., Dai, Y., Deng, B., Ding, S., Su, S., Sun, W., Li, Z. and Gan, Z. (2018) Distribution and Risk Assessment of Metals in Water, Sediments, and Wild Fish from Jinjiang River in Chengdu, China. Chemosphere, 196, 45-52. https://doi.org/10.1016/j.chemosphere.2017.12.135

[11] Zhang, M., Cui, L., Sheng, L. and Wang, Y. (2009) Distribution and Enrichment of Heavy Metals among Sediments, Water Body and Plants in Hengshuihu Wetland of Northern China. Ecological Engineering, 35, 563-569. 
https://doi.org/10.1016/j.ecoleng.2008.05.012

[12] Ling, M.-P., Wu, C.-C., Yang, K.-R. and Hsu, H.-T. (2013) Differential Accumulation of Trace Elements in Ventral and Dorsal Muscle Tissues in Tilapia and Milkfish with Different Feeding Habits from the Same Cultured Fishery Pond. Ecotoxicology and Environmental Safety, 89, 222-230. https://doi.org/10.1016/j.ecoenv.2012.12.002

[13] Zhao, Z., Chen, G. and Yang, R. (2017) Rapid Digestion of Soil Samples and Optimization of ICP-MS Conditions. Environmental Chemistry, 36, 1428-1431.

[14] Plessl, C., Gilbert, B.M., Sigmund, M.F., Theiner, S., Avenant-Oldewage, A., Keppler, B.K. and Jirsa, F. (2019) Mercury, Silver, Selenium and Other Trace Elements in Three Cyprinid Fish Species from the Vaal Dam, South Africa, Including Implications for Fish Consumers. Science of the Total Environment, 659, 1158-1167. https://doi.org/10.1016/j.scitotenv.2018.12.442

[15] Rao, Q., Sun, Z., Tian, L., Li, J., Sun, W. and Sun, W. (2018) Assessment of Arsenic and Heavy Metal Pollution and Ecological Risk in Inshore Sediments of the Yellow River Estuary, China. Stochastic Environmental Research and Risk Assessment, 32, 2889-2902. https://doi.org/10.1007/s00477-018-1588-Z

[16] Zhuang, Q., Li, G. and Liu, Z. (2018) Distribution, Source and Pollution Level of Heavy Metals in River Sediments from South China. Catena, 170, 386-396. https://doi.org/10.1016/j.catena.2018.06.037

[17] Hakanson, L. (1980) An Ecological Risk Index for Aquatic Pollution Control: A Sedimentological Approach. Water Research, 14, 975-1001. https://doi.org/10.1016/0043-1354(80)90143-8

[18] Zhu, H.-N., Yuan, X.-Z., Zeng, G.-M., Jiang, M., Liang, J., Zhang, C., Yin, J., Huang, H.-J., Liu, Z.-F. and Jiang, H.-W. (2012) Ecological Risk Assessment of Heavy Metals in Sediments of Xiawan Port Based on Modified Potential Ecological Risk Index. Transactions of Nonferrous Metals Society of China, 22, 1470-1477. https://doi.org/10.1016/S1003-6326(11)61343-5

[19] Marengo, M., Durieux, E.D.H., Ternengo, S., Lejeune, P., Degrange, E., Pasqualini, V. and Gobert, S. (2018) Comparison of Elemental Composition in Two Wild and Cultured Marine Fish and Potential Risks to Human Health. Ecotoxicology and Environmental Safety, 158, 204-212. https://doi.org/10.1016/j.ecoenv.2018.04.034

[20] Ahmed, A.S.S., Rahman, M., Sultana, S., Babu, S.M.O.F. and Sarker, M.S.I. (2019) Bioaccumulation and Heavy Metal Concentration in Tissues of Some Commercial Fishes from the Meghna River Estuary in Bangladesh and Human Health Implications. Marine Pollution Bulletin, 145, 436-447. https://doi.org/10.1016/j.marpolbul.2019.06.035

[21] Gu, Y.-G., Huang, H.-H. and Lin, Q. (2016) Concentrations and Human Health Implications of Heavy Metals in Wild Aquatic Organisms Captured from the Core Area of Daya Bay's Fishery Resource Reserve, South China Sea. Environmental Toxicology and Pharmacology, 45, 90-94. https://doi.org/10.1016/j.etap.2016.05.022

[22] Zhao, X.-M., Yao, L.-A., Ma, Q.-L., Zhou, G.-J., Wang, L., Fang, Q.-L. and Xu, Z.-C. (2018) Distribution and Ecological Risk Assessment of Cadmium in Water and Sediment in Longjiang River, China: Implication on Water Quality Management after Pollution Accident. Chemosphere, 194, 107-116. https://doi.org/10.1016/j.chemosphere.2017.11.127

[23] Shahsavani, A., Fakhri, Y., Ferrante, M., Keramati, H., Zandsalimi, Y., Bay, A., Pouya, S.R.H., Moradi, B., Bahmani, Z. and Khaneghah, A.M. (2017) Risk Assessment of Heavy Metals Bioaccumulation: Fished Shrimps from the Persian Gulf. Toxin Reviews, 
36, 322-330. https://doi.org/10.1080/15569543.2017.1312451

[24] Ma, W., Deng, F., Xu, Y., Xu, H., Nie, S., Li, J., Deng, H. and Li, H. (2005) The Study on Dietary Intake and Nutritional Status of Residents in Guangdong, South China. Preventive Medicine, 1, 1-5.

[25] Ju, Y.-R., Chen, C.-W., Chen, C.-F., Chuang, X.-Y. and Dong, C.-D. (2017) Assessment of Heavy Metals in Aquaculture Fishes Collected from Southwest Coast of Taiwan and Human Consumption Risk. International Biodeterioration \& Biodegradation, 124, 314-325. https://doi.org/10.1016/j.ibiod.2017.04.003

[26] Qu, L., Huang, H., Xia, F., Liu, Y., Dahlgren, R.A., Zhang, M. and Mei, K. (2018) Risk Analysis of Heavy Metal Concentration in Surface Waters across the Rural-Urban Interface of the Wen-Rui Tang River, China. Environmental Pollution, 237, 639-649. https://doi.org/10.1016/j.envpol.2018.02.020

[27] Zhang, H., Cui, B., Xiao, R. and Zhao, H. (2010) Heavy Metals in Water, Soils and Plants in Riparian Wetlands in the Pearl River Estuary, South China. Procedia Environmental Sciences, 2, 1344-1354. https://doi.org/10.1016/j.proenv.2010.10.145

[28] Xu, X., Huo, Q., Dong, Y., Zhang, S., Yang, Z., Xian, J., Yang, Y. and Cheng, Z. (2019) Bioaccumulation and Health Risk Assessment of Trace Metals in Fish from Freshwater Polyculture Ponds in Chengdu, China. Environmental Science and PolIution Research, 26, 33466-33477. https://doi.org/10.1007/s11356-019-06412-3

[29] Sharifi, Z., Hossaini, S.M.T. and Renella, G. (2016) Risk Assessment for Sediment and Stream Water Polluted by Heavy Metals Released by a Municipal Solid Waste Composting Plant. Journal of Geochemical Exploration, 169, 202-210. https://doi.org/10.1016/j.gexplo.2016.08.001

[30] Ayanda, I.O., Ekhator, U.I. and Bello, O.A. (2019) Determination of Selected Heavy Metal and Analysis of Proximate Composition in Some Fish Species from Ogun River, Southwestern Nigeria. Heliyon, 5, E02512. https://doi.org/10.1016/j.heliyon.2019.e02512

[31] WHO (1989) Heavy Metals Environmental Aspects, In: Environmental Health Criteria, World Health Organization, Geneva, 33.

[32] Agah, H., Leermakers, M., Elskens, M., Fatemi, S.M.R. and Baeyens, W. (2009) Accumulation of Trace Metals in the Muscle and Liver Tissues of Five Fish Species from the Persian Gulf. Environmental Monitoring and Assessment, 157, Article No.: 499. https://doi.org/10.1007/s10661-008-0551-8

[33] Tepe, Y., Turkmen, M. and Turkmen, A. (2008) Assessment of Heavy Metals in Two Commercial Fish Species of Four Turkish Seas. Environmental Monitoring and Assessment, 146, 277-284. https://doi.org/10.1007/s10661-007-0079-3

[34] Maurya, P.K., Malik, D.S., Yadav, K.K., Kumar, A., Kumar, S. and Kamyab, H. (2019) Bioaccumulation and Potential Sources of Heavy Metal Contamination in Fish Species in River Ganga Basin: Possible Human Health Risks Evaluation. Toxicology Reports, 6, 472-481. https://doi.org/10.1016/j.toxrep.2019.05.012

[35] Sobihah, N.N., Zaharin, A.A., Nizam, M.K., Juen, L.L. and Kyoung-Woong, K. (2018) Bioaccumulation of Heavy Metals in Maricultured Fish, Lates calcarifer (Barramudi), Lutjanus campechanus (Red Snapper) and Lutjanus griseus (Grey Snapper). Chemosphere, 197, 318-324.

https://doi.org/10.1016/j.chemosphere.2017.12.187

[36] Turkmen, M., Turkmen, A., Tepe, Y., Tore, Y. and Ates, A. (2009) Determination of Metals in Fish Species from Aegean and Mediterranean Seas. Food Chemistry, 113, 233-237. https://doi.org/10.1016/j.foodchem.2008.06.071

[37] Fang, T., Lu, W., Cui, K., Li, J., Yang, K., Zhao, X., Liang, Y. and Li, H. (2019) Dis- 
tribution, Bioaccumulation and Trophic Transfer of Trace Metals in the Food Web of Chaohu Lake, Anhui, China. Chemosphere, 218, 1122-1130. https://doi.org/10.1016/j.chemosphere.2018.10.107

[38] Huang, X., Qin, D., Gao, L., Hao, Q., Chen, Z., Wang, P., Tang, S., Wu, S., Jiang, H. and Qiu, W. (2019) Distribution, Contents and Health Risk Assessment of Heavy Metal(loid)s in Fish from Different Water Bodies in Northeast China. RSC Advances, 9, 33130-33139. https://doi.org/10.1039/C9RA05227E

[39] Vu, C.T., Chitsan, L., Gavin, Y. and Maria Ching, V. (2017) Bioaccumulation and Potential Sources of Heavy Metal Contamination in Fish Species in Taiwan: Assessment and Possible Human Health Implications. Environmental Science and Pollution Research, 24, 19422-19434. https://doi.org/10.1007/s11356-017-9590-4

[40] Anandkumar, A., Nagarajan, R., Prabakaran, K., Bing, C.H. and Rajaram, R. (2018) Human Health Risk Assessment and Bioaccumulation of Trace Metals in Fish Species Collected from the Miri Coast, Sarawak, Borneo. Marine Pollution Bulletin, 133, 655-663. https://doi.org/10.1016/j.marpolbul.2018.06.033

[41] European Commission (2006) Commission Regulation (EC) No 1881/2006 of 19 December 2006 Setting Maximum Levels for Certain Contaminants in Foodstuffs. Official Journal of the European Union, L364, 5-24.

[42] Gu, Y.-G., Lin, Q., Wang, X.-H., Du, F.-Y., Yu, Z.-L. and Huang, H.-H. (2015) Heavy Metal Concentrations in Wild Fishes Captured from the South China Sea and Associated Health Risks. Marine Pollution Bulletin, 96, 508-512. https://doi.org/10.1016/j.marpolbul.2015.04.022

[43] Kobla, H.V. and Volpe, S.L. (2000) Chromium, Exercise, and Body Composition. Critical Reviews in Food Science and Nutrition, 40, 291-308. https://doi.org/10.1080/10408690091189167

[44] Rahman, M.S., Molla, A.H., Saha, N. and Rahman, A. (2012) Study on Heavy Metals levels and Its Risk Assessment in Some Edible Fishes from Bangshi River, Savar, Dhaka, Bangladesh. Food Chemistry, 134, 1847-1854.

https://doi.org/10.1016/j.foodchem.2012.03.099

[45] China National Standard (2017) GB 2762-2017 China Food Safety National Standard for Maximum Levels of Contaminants in Foods.

[46] Forti, E., Salovaara, S., Cetin, Y., Bulgheroni, A., Tessadri, R., Jennings, P., Pfaller, W. and Prieto, P. (2011) In Vitro Evaluation of the Toxicity Induced by Nickel Soluble and Particulate Forms in Human Airway Epithelial Cells. Toxicology in Vitro, 25, 454-461. https://doi.org/10.1016/j.tiv.2010.11.013

[47] Garcia-Leston, J., Mendez, J., Pasaro, E. and Laffon, B. (2010) Genotoxic Effects of Lead: An Updated Review. Environment International, 36, 623-636. https://doi.org/10.1016/j.envint.2010.04.011

[48] Rogival, D., Scheirs, J. and Blust, R. (2007) Transfer and Accumulation of Metals in a Soil-Diet-Wood Mouse Food Chain along a Metal Pollution Gradient. Environmental Pollution, 145, 516-528. https://doi.org/10.1016/j.envpol.2006.04.019

[49] Ahmed, M.K., Shaheen, N., Islam, M.S., Habibullah-al-Mamun, M., Islam, S., Mohiduzzaman, M. and Bhattacharjee, L. (2015) Dietary Intake of Trace Elements from Highly Consumed Cultured Fish (Labeo rohita, Pangasius pangasius and Oreochromis mossambicus) and Human Health Risk Implications in Bangladesh. Chemosphere, 128, 284-292. https://doi.org/10.1016/j.chemosphere.2015.02.016

[50] JECFA (2011) Evaluation of Certain Food Additives and Contaminants Seventy-Third Report of the Joint FAO/WHO Expert Committee on Food Additives. Evaluation of Certain Food Additives and Contaminants. 


\section{Appendix A. Supplementary Data}

Supplementary data related to this article can be found at:

\section{Supporting Materials}

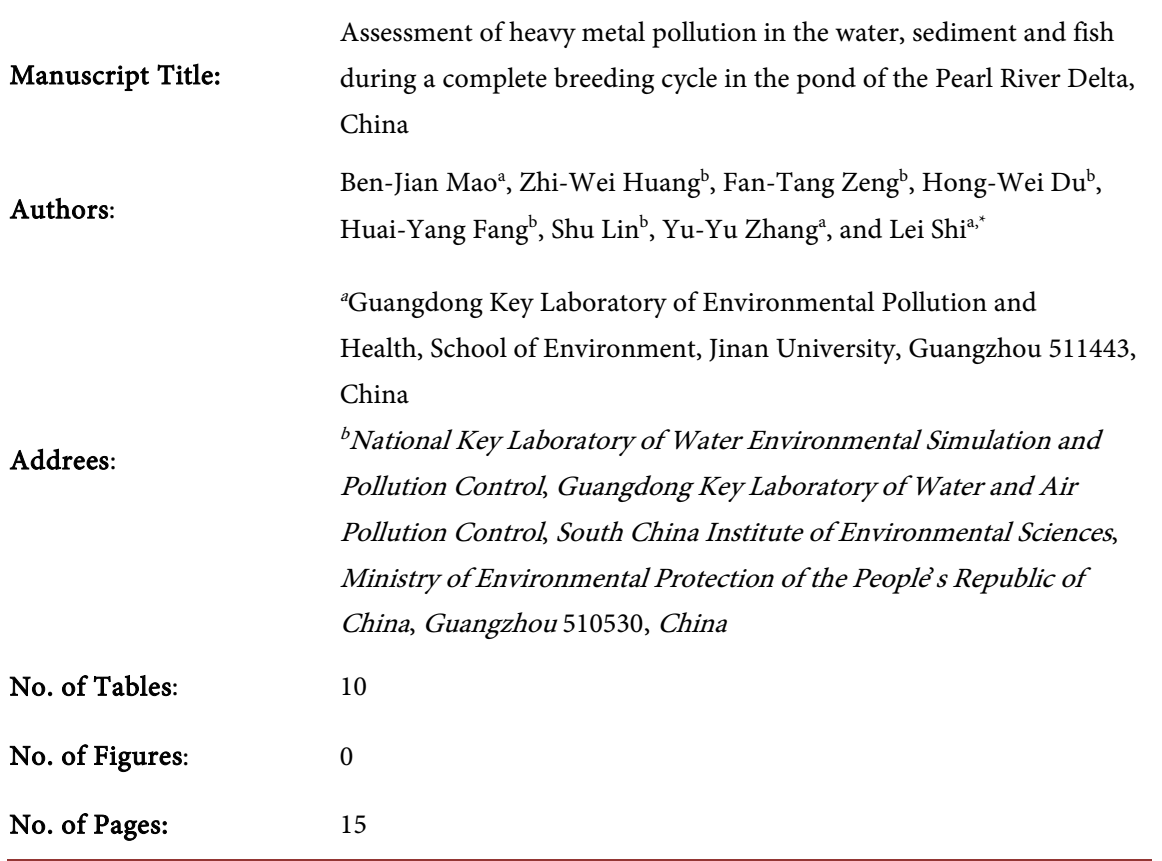

Table S1. Weight and length of grass carp in different growth period (fish age, month; weight, g; Length, cm) located in the pond of Pearl River Delta, China.

\begin{tabular}{ccccccc}
\hline Time & December & January & March & April & May & June \\
\hline Age & 6 & 7 & 9 & 10 & 11 & 12 \\
Weight & $232 \pm 55.2$ & $328 \pm 110$ & $418 \pm 60.0$ & $518 \pm 176$ & $810 \pm 116$ & $1180 \pm 277$ \\
Length & $24.4 \pm 3.86$ & $29.3 \pm 6.86$ & $31.8 \pm 2.88$ & $35.4 \pm 4.01$ & $40.0 \pm 1.77$ & $44.6 \pm 3.69$ \\
\hline
\end{tabular}

Table S2. Classification standards for geoaccumulation index $\left(I_{g e o}\right)$ in the pond sediment in the Pearl River Delta.

\begin{tabular}{ccc}
\hline Class & $I_{\text {geo }}$ & Pollution level \\
\hline 0 & $<0$ & uncontaminated \\
1 & {$[0,1]$} & moderately contaminated \\
2 & $(1,2]$ & moderately to heavily contaminated \\
3 & $(2,3]$ & heavily contaminated \\
4 & $(3,4]$ & heavily to extremely contaminated \\
5 & $(4,5]$ & extremely contaminated \\
6 & $>5$ &
\end{tabular}


Table S3. Sediment heavy metals ecological risks $\left(E_{i}\right)$ and comprehensive heavy metals ecological risks (RI) standard in the pond in Pearl River Delta.

\begin{tabular}{cccc}
\hline$E_{i}$ & risk level & RI & risk level \\
\hline$<40$ & Low risk & $<150$ & Low risk \\
$40-80$ & Moderate risk & $150-300$ & Moderate risk \\
$80-160$ & Considerable risk & $300-600$ & Considerable risk \\
$160-320$ & High risk & $>600$ & Extremely high risk \\
$>320$ & Extremely high risk & & \\
\hline
\end{tabular}

Table S4. Concentrations of heavy metals in the pond water of gull island in the Pearl River Delta $\left(\mu \mathrm{g} \cdot \mathrm{L}^{-1}\right)$.

\begin{tabular}{cccccccc}
\hline & $\mathrm{Cr}$ & $\mathrm{Ni}$ & $\mathrm{Cu}$ & $\mathrm{Zn}$ & $\mathrm{As}$ & $\mathrm{Cd}$ & $\mathrm{Pb}$ \\
\hline December & $0.00^{\mathrm{b}}$ & 0.46 & 0.42 & 8.69 & 0.00 & 0.00 & 0.00 \\
January & 0.00 & 0.89 & 7.61 & 40.3 & 0.00 & 0.00 & 2.45 \\
March & 4.56 & 2.18 & 13.8 & 69.1 & 5.32 & 0.00 & 4.28 \\
April & 1.83 & 1.85 & 3.61 & 55.7 & 3.74 & 0.01 & 1.83 \\
May & 2.87 & 2.87 & 2.73 & 64.1 & 5.37 & 0.02 & 1.55 \\
June & 1.57 & 4.87 & 6.12 & 54.5 & 4.27 & 0.01 & 2.17 \\
Range & $0.00-4.56$ & $0.46-4.87$ & $0.42-13.8$ & $8.69-69.1$ & $0.00-5.37$ & $0.00-0.02$ & $0.00-4.28$ \\
Mean \pm SD & $1.81 \pm 1.75$ & $2.19 \pm 1.58$ & $5.72 \pm 4.71$ & $48.7 \pm 21.9$ & $3.12 \pm 2.49$ & $0.01 \pm 0.01$ & $2.05 \pm 1.39$ \\
Fishery & 100 & 50 & 10 & 100 & 50 & 5 & 50 \\
\hline
\end{tabular}

${ }^{\mathrm{a} C h i n e s e}$ water quality standard for fisheries (GB11607-89) [28]. ${ }^{\mathrm{b}}$ Means data are not detected.

Table S5. Concentrations of heavy metals in fish feeds collected from the breeding base of gull island $\left(\mathrm{mg} \cdot \mathrm{kg}^{-1}\right)$.

\begin{tabular}{cccccccc}
\hline & $\mathrm{Cr}$ & $\mathrm{Ni}$ & $\mathrm{Cu}$ & $\mathrm{Zn}$ & $\mathrm{As}$ & $\mathrm{Cd}$ & $\mathrm{Pb}$ \\
\hline Range & $0.48-2.25$ & $1.19-3.60$ & $6.75-13.2$ & $64-112$ & $0.22-0.60$ & $0.03-0.09$ & $0.18-2.25$ \\
Mean $\pm \mathrm{SD}$ & $1.01 \pm 0.73$ & $2.5 \pm 0.81$ & $11.1 \pm 2.27$ & $95.3 \pm 16.6$ & $0.42 \pm 0.14$ & $0.06 \pm 0.02$ & $0.87 \pm 0.73$ \\
\hline
\end{tabular}

Table S6. Concentrations of heavy metals in the pond sediments in the Pearl River Delta $\left(\mathrm{mg} \cdot \mathrm{kg}^{-1}\right)$.

\begin{tabular}{cccccccc}
\hline & $\mathrm{Cr}$ & $\mathrm{Ni}$ & $\mathrm{Cu}$ & $\mathrm{Zn}$ & $\mathrm{As}$ & $\mathrm{Cd}$ & $\mathrm{Pb}$ \\
\hline December & 67.4 & 27.3 & 29.7 & 125 & 31.0 & 0.36 & 32.7 \\
January & 64.5 & 26.1 & 27.0 & 122 & 30.8 & 0.32 & 39.7 \\
March & 68.8 & 28.0 & 31.0 & 130 & 30.1 & 0.38 & 36.2 \\
April & 68.0 & 26.8 & 29.4 & 124 & 30.3 & 0.36 & 36.1 \\
May & 68.5 & 27.6 & 30.1 & 127 & 30.5 & 0.36 & 39.8 \\
June & 68.3 & 28.0 & 30.6 & 127 & 31.1 & 0.35 & 39.6 \\
Range & $64.5-68.8$ & $26.1-28.0$ & $27.0-31.0$ & $122-130$ & $30.1-31.1$ & $0.31-0.38$ & $32.7-39.8$ \\
Mean \pm SD & $67.6 \pm 1.60$ & $27.3 \pm 0.76$ & $29.6 \pm 1.40$ & $126 \pm 2.73$ & $30.6 \pm 0.41$ & $0.35 \pm 0.02$ & $37.4 \pm 2.86$ \\
Soil & 50.5 & 14.4 & 17.0 & 47.3 & 8.9 & 0.056 & 36 \\
\hline
\end{tabular}

${ }^{\mathrm{a}}$ Means soil background value in Guangdong Province, China [16]. 
Table S7. Heavy metal concentrations in different tissues collected from the pond located in the gull island during a complete culture cycle (unit: $\mathrm{mg} \cdot \mathrm{kg}^{-1}$, dry weight).

\begin{tabular}{|c|c|c|c|c|c|c|c|c|}
\hline Metals & Organs & December & January & March & April & May & June & Mean \\
\hline & Muscle & $0.00^{\mathrm{a}}$ & 0.00 & $0.25 \pm 0.09$ & 0.00 & $0.63 \pm 0.27$ & 0.00 & 0.15 \\
\hline & Skin & 0.00 & 0.00 & $0.59 \pm 0.12$ & $0.04 \pm 0.02$ & $0.68 \pm 0.82$ & $0.14 \pm 0.06$ & 0.24 \\
\hline & Bladder & 0.00 & $1.35 \pm 0.08$ & $0.74 \pm 0.18$ & 0.00 & 0.00 & $0.24 \pm 0.04$ & 0.39 \\
\hline & Gill & 0.00 & $0.33 \pm 0.19$ & $1.54 \pm 0.51$ & $0.04 \pm 0.02$ & $0.58 \pm 0.20$ & $0.31 \pm 0.09$ & 0.47 \\
\hline \multirow[t]{9}{*}{$\mathrm{Cr}$} & Heart & 0.00 & $8.01 \pm 1.28$ & $7.21 \pm 0.23$ & $0.03 \pm 0.003$ & 0.00 & $0.05 \pm 0.02$ & 2.55 \\
\hline & Kidney & $0.01 \pm 0.004$ & $4.45 \pm 0.31$ & $7.11 \pm 0.49$ & $0.04 \pm 0.01$ & $0.12 \pm 0.04$ & $0.12 \pm 0.05$ & 1.97 \\
\hline & Liver & 0.00 & 0.00 & $0.23 \pm 0.01$ & 0.00 & $0.06 \pm 0.03$ & $0.13 \pm 0.01$ & 0.07 \\
\hline & Mean & 0.001 & 2.02 & 2.52 & 0.02 & 0.30 & 0.14 & \\
\hline & Total & 0.01 & 14.1 & 17.7 & 0.14 & 2.08 & 0.98 & \\
\hline & Muscle & $0.03 \pm 0.03$ & $0.05 \pm 0.001$ & $0.04 \pm 0.02$ & $0.22 \pm 0.07$ & $0.81 \pm 0.25$ & $0.29 \pm 0.04$ & 0.24 \\
\hline & Skin & $0.05 \pm 0.01$ & $0.30 \pm 0.06$ & $1.04 \pm 0.41$ & $0.81 \pm 0.18$ & $0.47 \pm 0.29$ & $0.16 \pm 0.01$ & 0.47 \\
\hline & Bladder & $0.12 \pm 0.02$ & $0.15 \pm 0.05$ & $4.83 \pm 1.21$ & $3.20 \pm 0.53$ & $1.47 \pm 0.32$ & $0.18 \pm 0.03$ & 1.66 \\
\hline & Gill & $0.05 \pm 0.01$ & $0.27 \pm 0.04$ & $1.21 \pm 0.44$ & $4.34 \pm 1.17$ & $0.92 \pm 0.14$ & $0.31 \pm 0.11$ & 1.19 \\
\hline \multirow[t]{9}{*}{$\mathrm{Ni}$} & Heart & $0.16 \pm 0.02$ & $0.15 \pm 0.03$ & $0.11 \pm 0.05$ & $0.07 \pm 0.01$ & $0.01 \pm 0.01$ & $0.01 \pm 0.01$ & 0.08 \\
\hline & Kidney & $0.13 \pm 0.01$ & $0.14 \pm 0.07$ & $0.18 \pm 0.08$ & $0.14 \pm 0.08$ & $0.07 \pm 0.01$ & $0.04 \pm 0.01$ & 0.12 \\
\hline & Liver & 0.00 & 0.00 & $0.02 \pm 0.01$ & $0.03 \pm 0.17$ & $0.04 \pm 0.03$ & $0.01 \pm 0.004$ & 0.02 \\
\hline & Mean & 0.08 & 0.03 & 1.06 & 1.26 & 0.54 & 0.10 & \\
\hline & Total & 0.53 & 0.18 & 7.42 & 8.80 & 3.79 & 0.71 & \\
\hline & Muscle & $1.56 \pm 0.21$ & $2.00 \pm 0.08$ & $2.04 \pm 0.06$ & $1.95 \pm 0.32$ & $2.19 \pm 0.05$ & $1.41 \pm 0.07$ & 1.86 \\
\hline & Skin & $1.44 \pm 0.09$ & $2.06 \pm 0.16$ & $1.71 \pm 0.26$ & $1.59 \pm 0.19$ & $1.79 \pm 0.09$ & $0.79 \pm 0.02$ & 1.56 \\
\hline & Bladder & $1.34 \pm 0.16$ & $3.32 \pm 0.42$ & $2.44 \pm 0.39$ & $1.98 \pm 0.30$ & $1.48 \pm 0.13$ & $0.86 \pm 0.04$ & 1.90 \\
\hline & Gill & $2.42 \pm 0.12$ & $2.69 \pm 0.13$ & $4.66 \pm 1.63$ & $3.64 \pm 0.27$ & $3.26 \pm 0.23$ & $1.86 \pm 0.03$ & 3.09 \\
\hline \multirow[t]{9}{*}{$\mathrm{Cu}$} & Heart & $10.9 \pm 1.79$ & $11.2 \pm 1.70$ & $9.50 \pm 0.80$ & $7.19 \pm 0.23$ & $8.47 \pm 0.72$ & $6.87 \pm 0.39$ & 9.01 \\
\hline & Kidney & $5.18 \pm 0.43$ & $5.70 \pm 0.31$ & $5.26 \pm 0.72$ & $6.61 \pm 0.09$ & $8.19 \pm 0.12$ & $5.26 \pm 0.14$ & 6.03 \\
\hline & Liver & $6.07 \pm 0.09$ & $5.71 \pm 0.06$ & $11.7 \pm 0.50$ & $23.1 \pm 1.93$ & $10.6 \pm 0.57$ & $9.45 \pm 0.66$ & 11.1 \\
\hline & Mean & 4.13 & 4.66 & 5.32 & 6.58 & 5.14 & 3.58 & \\
\hline & Total & 28.9 & 32.6 & 37.3 & 46.0 & 36.0 & 25.1 & \\
\hline & Muscle & $28.7 \pm 3.97$ & $18.6 \pm 3.79$ & $27.8 \pm 5.05$ & $20.1 \pm 2.32$ & $35.7 \pm 3.72$ & $20.5 \pm 3.36$ & 25.2 \\
\hline & Skin & $230 \pm 4.51$ & $137 \pm 8.80$ & $137 \pm 10.0$ & $136 \pm 4.36$ & $259 \pm 20.5$ & $117 \pm 6.16$ & 169 \\
\hline & Bladder & $68.4 \pm 5.53$ & $44.4 \pm 3.64$ & $46.4 \pm 3.03$ & $38.7 \pm 5.63$ & $57.9 \pm 2.58$ & $23.3 \pm 3.67$ & 46.5 \\
\hline & Gill & $76.1 \pm 1.68$ & $65.1 \pm 2.88$ & $75.7 \pm 4.74$ & $61.9 \pm 2.70$ & $102 \pm 10.1$ & $52.5 \pm 0.73$ & 72.3 \\
\hline \multirow[t]{4}{*}{$\mathrm{Zn}$} & Heart & $82.9 \pm 3.79$ & $66.8 \pm 9.96$ & $67.0 \pm 1.53$ & $50.9 \pm 4.78$ & $81.2 \pm 5.27$ & $54.8 \pm 2.77$ & 67.3 \\
\hline & Kidney & $90.2 \pm 3.24$ & $77.7 \pm 1.16$ & $70.0 \pm 4.85$ & $65.0 \pm 1.32$ & $118 \pm 3.40$ & $56.0 \pm 2.24$ & 79.5 \\
\hline & Liver & $61.8 \pm 2.14$ & $43.8 \pm 0.71$ & $62.3 \pm 2.26$ & $71.1 \pm 6.15$ & $74.8 \pm 5.28$ & $56.4 \pm 3.27$ & 61.7 \\
\hline & Mean & 91.2 & 64.8 & 69.4 & 63.4 & 104 & 51.5 & \\
\hline
\end{tabular}




\section{Continued}

\begin{tabular}{|c|c|c|c|c|c|c|c|c|}
\hline & Total & 639 & 453 & 486 & 444 & 729 & 360 & \\
\hline & Muscle & 0.00 & 0.00 & $0.06 \pm 0.004$ & $0.07 \pm 0.01$ & $0.05 \pm 0.01$ & $0.05 \pm 0.01$ & 0.04 \\
\hline & Skin & 0.00 & 0.00 & $0.08 \pm 0.01$ & $0.07 \pm 0.02$ & $0.04 \pm 0.01$ & $0.06 \pm 0.01$ & 0.04 \\
\hline & Bladder & 0.00 & 0.00 & $0.06 \pm 0.01$ & $0.02 \pm 0.01$ & 0.00 & $0.04 \pm 0.01$ & 0.02 \\
\hline & Gill & 0.00 & 0.00 & $0.07 \pm 0.03$ & $0.08 \pm 0.01$ & $0.10 \pm 0.01$ & $0.08 \pm 0.01$ & 0.06 \\
\hline \multirow[t]{9}{*}{ As } & Heart & 0.00 & 0.00 & $0.03 \pm 0.003$ & $0.08 \pm 0.02$ & $0.04 \pm 0.01$ & $0.12 \pm 0.01$ & 0.04 \\
\hline & Kidney & 0.00 & 0.00 & $0.03 \pm 0.01$ & $0.09 \pm 0.01$ & $0.07 \pm 0.02$ & $0.13 \pm 0.01$ & 0.06 \\
\hline & Liver & 0.00 & 0.00 & $0.06 \pm 0.01$ & $0.06 \pm 0.02$ & $0.04 \pm 0.01$ & $0.10 \pm 0.01$ & 0.04 \\
\hline & Mean & $-b$ & - & 0.06 & 0.07 & 0.05 & 0.08 & \\
\hline & Total & - & - & 0.39 & 0.46 & 0.34 & 0.53 & \\
\hline & Muscle & 0.00 & 0.00 & 0.00 & 0.00 & 0.00 & 0.00 & - \\
\hline & Skin & 0.00 & 0.00 & 0.00 & $0.001 \pm 0.001$ & 0.00 & 0.00 & 0.0002 \\
\hline & Bladder & 0.00 & $0.01 \pm 0.001$ & $0.001 \pm 0.001$ & $0.002 \pm 0.001$ & 0.00 & 0.00 & 0.002 \\
\hline & Gill & 0.00 & $0.01 \pm 0.0001$ & $0.05 \pm 0.01$ & $0.004 \pm 0.001$ & $0.002 \pm 0.001$ & $0.003 \pm 0.001$ & 0.01 \\
\hline \multirow[t]{9}{*}{$\mathrm{Cd}$} & Heart & 0.00 & 0.00 & $0.004 \pm 0.003$ & $0.003 \pm 0.002$ & $0.002 \pm 0.002$ & $0.001 \pm 0.0002$ & 0.002 \\
\hline & Kidney & 0.00 & $0.05 \pm 0.003$ & $0.04 \pm 0.01$ & $0.13 \pm 0.003$ & $0.09 \pm 0.01$ & $0.06 \pm 0.01$ & 0.06 \\
\hline & Liver & 0.00 & $0.01 \pm 0.0004$ & $0.02 \pm 0.001$ & $0.04 \pm 0.01$ & $0.02 \pm 0.002$ & $0.01 \pm 0.002$ & 0.02 \\
\hline & Mean & - & 0.01 & 0.02 & 0.03 & 0.02 & 0.01 & \\
\hline & Total & - & 0.08 & 0.11 & 0.18 & 0.11 & 0.08 & \\
\hline & Muscle & 0.00 & 0.00 & 0.00 & 0.00 & 0.00 & 0.00 & - \\
\hline & Skin & $0.09 \pm 0.003$ & 0.00 & $0.09 \pm 0.09$ & $0.04 \pm 0.02$ & 0.00 & $0.02 \pm 0.01$ & 0.04 \\
\hline & Bladder & 0.00 & $0.18 \pm 0.03$ & $0.05 \pm 0.04$ & 0.00 & 0.00 & 0.00 & 0.04 \\
\hline & Gill & $1.40 \pm 0.14$ & $0.25 \pm 0.06$ & $0.44 \pm 0.02$ & $0.04 \pm 0.02$ & $0.26 \pm 0.08$ & $0.15 \pm 0.08$ & 0.42 \\
\hline \multirow[t]{5}{*}{$\mathrm{Pb}$} & Heart & $0.09 \pm 0.002$ & 0.00 & $0.07 \pm 0.03$ & $0.03 \pm 0.003$ & 0.00 & $0.04 \pm 0.01$ & 0.04 \\
\hline & Kidney & $0.03 \pm 0.01$ & 0.00 & $0.08 \pm 0.02$ & $0.04 \pm 0.01$ & $0.10 \pm 0.03$ & $0.13 \pm 0.02$ & 0.06 \\
\hline & Liver & 0.00 & 0.00 & $0.01 \pm 0.01$ & 0.00 & 0.00 & $0.003 \pm 0.001$ & 0.003 \\
\hline & Mean & 0.23 & 0.06 & 0.11 & 0.02 & 0.05 & 0.05 & \\
\hline & Total & 1.61 & 0.43 & 0.74 & 0.14 & 0.35 & 0.34 & \\
\hline
\end{tabular}

${ }^{\mathrm{a}}$ Means data are not detected. ${ }^{\mathrm{b}}$ Means data are not available.

Table S8. The values of calculated geoaccumulation index $\left(I_{g e o}\right)$, heavy metals ecological risks $\left(E_{i}\right)$ and comprehensive heavy metals ecological risks (RI) in the pond sediment of the Pearl River Delta.

\begin{tabular}{|c|c|c|c|c|c|c|c|}
\hline & $\mathrm{Cr}$ & $\mathrm{Ni}$ & $\mathrm{Cu}$ & $\mathrm{Zn}$ & As & $\mathrm{Cd}$ & $\mathrm{Pb}$ \\
\hline$I_{g e o}$ & $-0.16 \pm 0.03$ & $0.34 \pm 0.04$ & $0.22 \pm 0.07$ & $0.83 \pm 0.03$ & $1.20 \pm 0.02$ & $2.08 \pm 0.08$ & $-0.53 \pm 0.11$ \\
\hline$E_{i}$ & $2.68 \pm 0.06$ & $9.48 \pm 0.26$ & $8.71 \pm 0.41$ & $2.67 \pm 0.06$ & $34.4 \pm 0.46$ & $190 \pm 10.8$ & $5.19 \pm 0.40$ \\
\hline RI & $253 \pm 11$ & & & & & & \\
\hline
\end{tabular}


Table S9. The estimated daily intake (EDI) and the provisional tolerable daily intake (PTDI) [ug. $\left.(\mathrm{kg} \cdot \mathrm{d})^{-1}\right]$ in fish collected from the pond located in the Pearl River Delta.

\begin{tabular}{ccccccccc}
\hline & & \multicolumn{3}{c}{ EDI } & & & \\
& & $\mathrm{Cr}$ & $\mathrm{Ni}$ & $\mathrm{Cu}$ & $\mathrm{Zn}$ & $\mathrm{As}$ & $\mathrm{Cd}$ & $\mathrm{Pb}$ \\
\hline December & $6 \times 10^{-4}$ & 0.02 & 1.35 & 24.8 & $4 \times 10^{-5}$ & $1 \times 10^{-5}$ & $2 \times 10^{-4}$ \\
January & $6 \times 10^{-4}$ & 0.05 & 1.72 & 16.1 & $4 \times 10^{-5}$ & $1 \times 10^{-5}$ & $2 \times 10^{-4}$ \\
March & 0.21 & 0.04 & 1.76 & 24.0 & 0.05 & $1 \times 10^{-5}$ & $2 \times 10^{-4}$ \\
April & $6 \times 10^{-4}$ & 0.19 & 1.69 & 17.4 & 0.06 & $1 \times 10^{-5}$ & $2 \times 10^{-4}$ \\
May & 0.54 & 0.70 & 1.89 & 30.8 & 0.04 & $1 \times 10^{-5}$ & $2 \times 10^{-4}$ \\
June & $6 \times 10^{-4}$ & 0.25 & 1.21 & 17.7 & 0.04 & $1 \times 10^{-5}$ & $2 \times 10^{-4}$ \\
PTDI & 300 & 14 & 500 & 300 & 214 & 0.8 & 1.5 \\
\hline
\end{tabular}

aJoint FAO/WHO Expert Committee on Food Additives [50].

Table S10. Calculated values of target hazard quotient (THQ), hazard index (HI) and carcinogenic risk (CR) in the fish muscle collected from the pond located in the Pearl River Delta.

\begin{tabular}{|c|c|c|c|c|c|c|c|c|c|c|}
\hline & \multicolumn{10}{|c|}{ THQ } \\
\hline & $\mathrm{Cr}$ & $\mathrm{Ni}$ & $\mathrm{Cu}$ & $\mathrm{Zn}$ & As & $\mathrm{Cd}$ & $\mathrm{Pb}$ & $\mathrm{HI}$ & CR(As) & $\mathrm{CR}(\mathrm{Cd})$ \\
\hline December & $1.14 \times 10^{-4}$ & $1.15 \times 10^{-3}$ & $3.37 \times 10^{-2}$ & $8.26 \times 10^{-2}$ & $1.48 \times 10^{-5}$ & $1.33 \times 10^{-5}$ & $1.48 \times 10^{-4}$ & 0.12 & $6.65 \times 10^{-8}$ & $7.99 \times 10^{-8}$ \\
\hline January & $1.14 \times 10^{-4}$ & $2.31 \times 10^{-3}$ & $4.31 \times 10^{-2}$ & $5.35 \times 10^{-2}$ & $1.48 \times 10^{-5}$ & $1.33 \times 10^{-5}$ & $1.48 \times 10^{-4}$ & 0.10 & $6.65 \times 10^{-8}$ & $7.99 \times 10^{-8}$ \\
\hline March & $4.30 \times 10^{-2}$ & $1.82 \times 10^{-3}$ & $4.40 \times 10^{-2}$ & $7.99 \times 10^{-2}$ & $1.79 \times 10^{-2}$ & $1.33 \times 10^{-5}$ & $1.48 \times 10^{-4}$ & 0.19 & $8.07 \times 10^{-5}$ & $7.99 \times 10^{-8}$ \\
\hline April & $1.14 \times 10^{-4}$ & $9.41 \times 10^{-3}$ & $4.21 \times 10^{-2}$ & $5.79 \times 10^{-2}$ & $1.97 \times 10^{-2}$ & $1.33 \times 10^{-5}$ & $1.48 \times 10^{-4}$ & 0.13 & $8.86 \times 10^{-5}$ & $7.99 \times 10^{-8}$ \\
\hline May & $1.09 \times 10^{-1}$ & $3.50 \times 10^{-2}$ & $4.73 \times 10^{-2}$ & $1.03 \times 10^{-1}$ & $1.43 \times 10^{-2}$ & $1.33 \times 10^{-5}$ & $1.48 \times 10^{-4}$ & 0.31 & $6.42 \times 10^{-5}$ & $7.99 \times 10^{-8}$ \\
\hline June & $1.14 \times 10^{-4}$ & $1.25 \times 10^{-2}$ & $3.04 \times 10^{-2}$ & $5.89 \times 10^{-2}$ & $1.34 \times 10^{-2}$ & $1.33 \times 10^{-5}$ & $1.48 \times 10^{-4}$ & 0.12 & $6.02 \times 10^{-5}$ & $7.99 \times 10^{-8}$ \\
\hline
\end{tabular}

